\title{
ANALISIS CAMPUR KODE DALAM CERAMAH \\ KYAI HAJI ZAINUDDIN MZ \\ (KAJIAN SOSIOLUNGISTIK)
}

\author{
Muhamad Fathoni \\ STAI Masjid Syuhada Yogyakarta \\ muh.fathoni25@gmail.com
}

\begin{abstract}
Abstrak
Analisis ini bertujuan untuk mengetahui campur kode dalam ceramah KH. Zainuddin M.Z, dengan pendekatan Kajian Sosiolingustik. Hasil analisis pada ceremah KH. Zainuddin M.Z, yaitu: (1) terdapat empat bentuk penyisipan yaitu: kata, frase, idom dan klausa. (2) terdapat dua jenis campur kode, yaitu: campur kode keluar (outer code-mixing), karena bahasa yang dicampurkan merupakan bahasa asing yakni bahasa Arab dan bahasa Inggris, dan campur kode ke dalam (Inner Code Mixing), karena bahasa yang dicampurkan merupakan bahasa asing yakni bahasa Jawa. (3) Fungsi campur kode dalam ceramah KH. Zainuddin M.Z yaitu: sebagai perulangan, sebagai penyisip kalimat, dan sebagai kutipan. Adapun (4) faktor penyebab terjadinya campur kode dalam ceramah KH. Zainuddin M.Z yaitu: faktor penutur sendiri dan faktor kebiasaan.
\end{abstract}

Kata kunci: Campur kode, Sosiolinguistik.

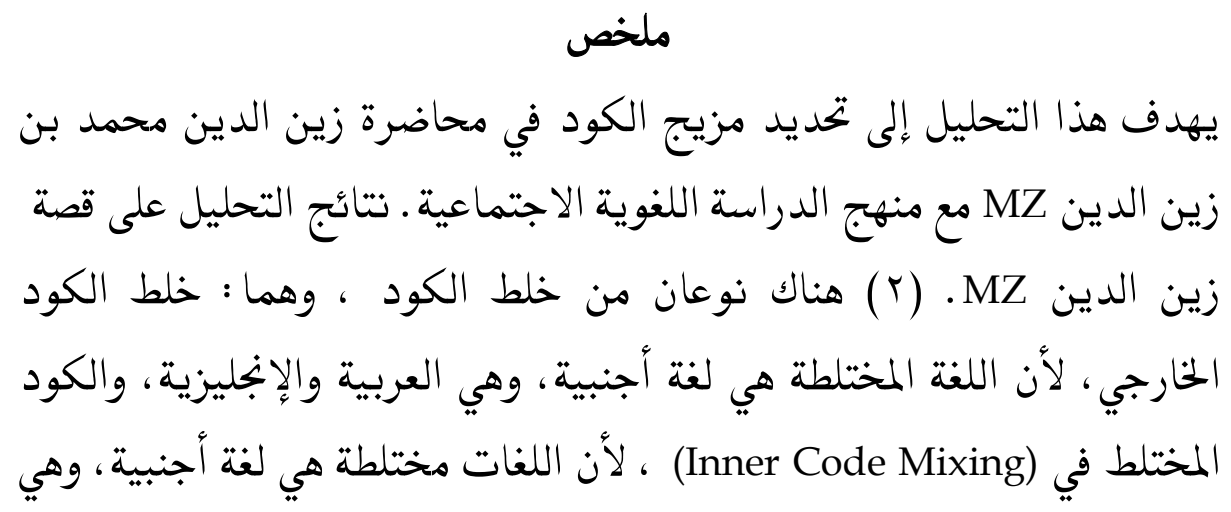




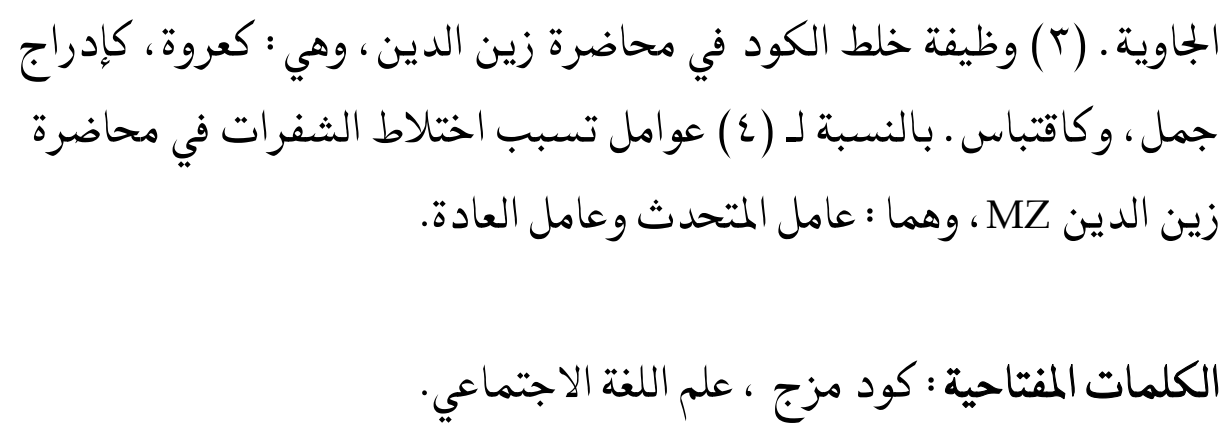

\section{Pendahuluan}

Bahasa sebagai alat komunikasi yang digunakan oleh setiap individu dalam proses interaksi untuk saling berbagi informasi ataupun untuk saling bertukar pikiran dengan orang lain. Dalam suatu masyarakat tidak mungkin dapat berkomunikasi apabila anggota masyarakat tersebut tanpa menggunakan bahasa sebagai media atau sarananya. Jika kita tidak mempunyai bahasa, kita tidak akan bisa hidup sebagai mahluk sosial. ${ }^{80}$ Oleh sebab itu bahasa memegang peranan yang sangat penting dalam roda kehidupan, karena manusia adalah makhluk sosial yang di dalam kesehariannya membutuhkan bahasa sebagai alat komunikasi. Bahasa manusia adalah sejenis kode, sistem bahasa dalam suatu masyarakat, variasi tertentu dalam suatu bahasa. ${ }^{81}$ Sedangkan kode adalah suatu sistemstruktur yang penerapan unsur-unsurnya mempunyai ciri-ciri khas, sesuai denga latar belakang penutur,

${ }^{80}$ Nababan, P.W.J., Sosioliguistik Suatu Pengajaran, Jakarta: Gramedia, 1983, hlm. 46

${ }^{81}$ Harimurti Kridalaksana, Kamus Linguistik, Jakarta: Gramedia Pustaka Utama, 2008, hlm. 127 
relasi penutur dengan mitra tutur dan situasi yang ada. ${ }^{82}$ Fenomena kebahasaan seperti ini termasuk dalam kajian Sosiolinguistik. Penutur tidak akan lepas dari ciri-ciri penutur, kondisi sosial masyarakat, dan sosiobudaya dari penutur itu sendiri, maka bahasa daerah satu dengan yang dapat berbeda-beda. ${ }^{83}$

Bahasa salah satunya digunakan untuk menyampaikan sebuah informasi melalui pembicaraan dari seorang penutur kepada lawan tutur atau pendengar. Pada saat proses berbicara seorang penutur juga harus mempertimbangkan lawan tutur atau pendengarnya, apakah pendengar adalah individu yang lebih muda atau lebih tua, atau bahkan pendengar adalah masyarakat umum. Salah satu bentuk penyampaian informasi atau pesan kepada masyarakat umum atau publik adalah ceramah. Ceramah lebih dominakan penyampain pesan yang bersifat keagamaan. Bahasa yang digunakan dalam ceramah sering dijumpai aspek campur kode (code mixing) baik bilingual maupun multilingual. campur kode adalah penggunaan satuan bahasa dari satu bahasa ke bahasa lain untuk memperluas gaya bahasa atau ragam bahasa, termasuk di dalamnya pemakaian kata, frasa, klausa, idiom, dan sapaan. ${ }^{84}$ hal itu dikarenakan pendengar yang memiliki latar belakang yang berbeda-beda, maka pesan juga harus disampaikan

82 Kunjana Rahardi, Kajian Sosiolinguistik. Bogor: Ghalia Indonesia, 2010, hlm.55

83 Abdul Chaer dan Leonie Agustina, Sosiolinguistik: Perkenalan Awal, Jakarta: Rineka Cipta, 2014, hlm. 2-4

${ }^{84}$ Kridalaksana, op.cit, hlm. 40 
Muhamad Fathoni : Analisis Campur Kode Dalam Ceramah Kyai Haji Zainuddin MZ (Kajian Sosiolungistik)

mengunakan ragam bahasa yang berbeda. Seorang penceramah dituntut untuk dapat menggunakan bahasa yang baik dan menarik, oleh karena itu penceramah biasanya menggunakan pencampuran bahasa agar lebih menarik, mengesan dan tidak membosankan.

Salah satu penceramah yang memiliki keunikan bahasa adalah almarhum Kyai Haji (K.H.) Zainuddin Hamini atau yang lebih dikenal dengan K.H. Zainuddin MZ beliau adalah seorang pemuka agama Islam di Indonesia yang populer melalui ceramahceramahnya di radio dan televisi. Julukannya adalah "Dai Sejuta Umat" karena dakwahnya yang dapat menyentuh seluruh lapisan masyarakat. Beliau sering menggunakan campur kode bahasa dalam ceramahnya.

\section{Analisis Campur Kode Dalam Ceramah Kyai Haji Zaenuddin MZ}

Penelitian ini merupakan penelitian Kualitatif dengan pendekatan Sosiolinguistik dengan subjek penelitian rekaman ceramah K.H. Zainuddin MZ yang berjudul: (1) Jaman Susah, (2) Keluarga Sakinah, (3) Refomasi Baginda Nabi Muhammad SAW, dan (4) Akhirat. Objek penelitian adalah keseluruhan data yang berhubungan dengan campur kode ragam bahasa resmi dan tidak resmi yang digunakan oleh K.H. Zainuddin MZ dalam ceramah agama.

Teknik pengumpulan data dalam penelitian ini dengan menggunakan metode dengar dan catat, dengan menyajikan datadata yang objektif mengenai campur kode antara ragam bahasa 
resmi dan tidak resmi yang digunakan oleh K.H. Zainuddin MZ dalam ceramah agama. Penelitian ini menggunakan analisis deskriptif kualitatif yang digunakan untuk menggambarkan atau mendeskripsikan data-data yang diperoleh melalui studi deskriptif. Penelitian ini tidak mengutamakan angka-angka tetapi mengutamakan penghayatan terhadap interaksi antar konsep yang dikaji secara empiris.

Bahasa yang digunakan K.H. Zainuddin MZ dalam ceramahnya yang berjudul: Jaman Susah, Keluarga Sakinah, Refomasi Baginda Nabi Muhammad SAW, dan Akhirat, terdapat beberapa campur kode berupa kata, frase, klausa, dan kalimat, dengan penjelasan sebagai berikut:

1. Rekaman ceramah berjudul "Jaman Susah"

\begin{tabular}{|c|l|l|}
\hline NO & \multicolumn{1}{|c|}{ TEKS } & \multicolumn{1}{c|}{ ANALISIS } \\
\hline 1 & $\begin{array}{l}\text { "ditengah perubahan- } \\
\text { perubahan yang } \\
\text { terjadi begitu cepat } \\
\text { what must we do know?" }\end{array}$ & $\begin{array}{l}\text { Dalam ucapan tersebut } \\
\text { terdapat campur kode yang } \\
\text { berupa Klausa, yaitu } \\
\text { masuknya unsur bahasa } \\
\text { Inggris 'what must we do know?' } \\
\text { ke dalam tuturan bahasa } \\
\text { Indonesia yang berarti 'apa } \\
\text { yang harus kita lakukan } \\
\text { sekarang?'. }\end{array}$ \\
\hline 2 & $\begin{array}{l}\text { “Jangan sampai mbah } \\
\text { dukun yang muncul ke } \\
\text { permukaan" }\end{array}$ & $\begin{array}{l}\text { Dalam ucapan tersebut } \\
\text { terdapat campur kode yang } \\
\text { berupa frase, yaitu masuknya } \\
\text { unsur bahasa Jawa 'mbah } \\
\text { dukun' ke dalam tuturan }\end{array}$ \\
\hline
\end{tabular}


Muhamad Fathoni : Analisis Campur Kode Dalam Ceramah Kyai Haji Zainuddin MZ (Kajian Sosiolungistik)

\begin{tabular}{|c|c|c|}
\hline NO & TEKS & ANALISIS \\
\hline & & $\begin{array}{l}\text { bahasa Indonesia yang } \\
\text { berarti 'Paranormal'. }\end{array}$ \\
\hline 3 & $\begin{array}{l}\text { "dimasyarakat muncul } \\
\text { street justice sebagai } \\
\text { refleksi dari ketidak } \\
\text { puasan melihat } \\
\text { hukum" }\end{array}$ & $\begin{array}{l}\text { Dalam ucapan tersebut } \\
\text { terdapat campur kode yang } \\
\text { berupa frase, yaitu masuknya } \\
\text { unsur bahasa Inggris 'street } \\
\text { justice' ke dalam tuturan } \\
\text { bahasa Indonesia yang } \\
\text { berarti 'pengadilan jalanan'. }\end{array}$ \\
\hline 4 & $\begin{array}{l}\text { "yang ada didalam } \\
\text { diri itu role of thinking, } \\
\text { state of mind" }\end{array}$ & $\begin{array}{l}\text { Dalam ucapan tersebut } \\
\text { terdapat campur kode yang } \\
\text { berupa frase, yaitu masuknya } \\
\text { unsur bahasa Inggris 'role of } \\
\text { thinking' dan 'state of mind' ke } \\
\text { dalam tuturan bahasa } \\
\text { Indonesia yang berarti 'peran } \\
\text { berfikir' dan 'kondisi berpikir'. }\end{array}$ \\
\hline 5 & $\begin{array}{l}\text { "kita ini sebagai } \\
\text { Bangsa mengalami apa } \\
\text { yang sisebut oleh Bung } \\
\text { Karno up and down" }\end{array}$ & $\begin{array}{l}\text { Dalam ucapan tersebut } \\
\text { terdapat campur kode yang } \\
\text { berupa frase, yaitu masuknya } \\
\text { unsur bahasa Inggris 'up and } \\
\text { down' ke dalam tuturan } \\
\text { bahasa Indonesia yang } \\
\text { berarti 'peran berfikir'. }\end{array}$ \\
\hline 6 & $\begin{array}{l}\text { "Jauh sebelum } \\
\text { Amirika teriak-teriak } \\
\text { membanggaken apa } \\
\text { yang mereka sebut } \\
\text { sebagai declaration of } \\
\text { independence" }\end{array}$ & $\begin{array}{l}\text { Dalam ucapan tersebut } \\
\text { terdapat campur kode yang } \\
\text { berupa frase, yaitu masuknya } \\
\text { unsur bahasa Inggris } \\
\text { 'declaration of independence' ke } \\
\text { dalam tuturan bahasa }\end{array}$ \\
\hline
\end{tabular}




\begin{tabular}{|c|c|c|}
\hline NO & TEKS & ANALISIS \\
\hline & & $\begin{array}{l}\text { Indonesia yang berarti } \\
\text { 'deklarasi kemerdekaan'. }\end{array}$ \\
\hline 7 & $\begin{array}{l}\text { "jauh sebelum } \\
\text { Amirika } \\
\text { mencanangken bahwa } \\
\text { semua manusia } \\
\text { dilahirken sama that all } \\
\text { men are created equal" }\end{array}$ & $\begin{array}{l}\text { Dalam ucapan tersebut } \\
\text { terdapat campur kode yang } \\
\text { berupa Klausa, yaitu } \\
\text { masuknya unsur bahasa } \\
\text { Inggris 'that all men are created } \\
\text { equal' ke dalam tuturan } \\
\text { bahasa Indonesia yang } \\
\text { berarti 'bahwa semua } \\
\text { manusia diciptakan sama'. }\end{array}$ \\
\hline 8 & $\begin{array}{l}\text { "Islam ini Rakhmatan lil } \\
\text { 'Alamin jangankan } \\
\text { manusia yang berbeda } \\
\text { agama, hewan pun } \\
\text { dihormati" }\end{array}$ & $\begin{array}{l}\text { Dalam ucapan tersebut } \\
\text { terdapat campur kode yang } \\
\text { berupa Klausa, yaitu } \\
\text { masuknya unsur bahasa Arab, } \\
\text { 'Rakhmatan lil 'Alamin' ke } \\
\text { dalam tuturan bahasa } \\
\text { Indonesia yang berarti } \\
\text { 'rahmat bagi seluruh alam'. }\end{array}$ \\
\hline
\end{tabular}

2. Rekaman ceramah berjudul "Keluarga Sakinah"

\begin{tabular}{|c|l|l|}
\hline NO & \multicolumn{1}{|c|}{ TEKS } & \multicolumn{1}{c|}{ ANALISIS } \\
\hline 1 & $\begin{array}{l}\text { "tentu setelah sore soak } \\
\text { batrenya." }\end{array}$ & $\begin{array}{l}\text { Dalam ucapan tersebut } \\
\text { terdapat campur kode yang } \\
\text { berupa kata, yaitu masuknya } \\
\text { unsur bahasa Jawa, 'soak' ke } \\
\text { dalam tuturan bahasa } \\
\end{array}$ \\
& & Indonesia yang berarti 'rusak'. \\
\hline 2 & "kita tahu yang & Dalam uacapan tersebut \\
\hline
\end{tabular}


Muhamad Fathoni : Analisis Campur Kode Dalam Ceramah Kyai Haji Zainuddin MZ (Kajian Sosiolungistik)

\begin{tabular}{|c|c|c|}
\hline NO & TEKS & ANALISIS \\
\hline & $\begin{array}{l}\text { namanya Bajing itu } \\
\text { makannya cuma } \\
\text { kelapa, tapi bajingan } \\
\text { itu bukan cuma kelapa } \\
\text { wong kabel telpon ja } \\
\text { doyan kok bajingan itu". }\end{array}$ & $\begin{array}{l}\text { terdapat campur kode yang } \\
\text { berupa klausa, yaitu } \\
\text { masuknya unsur bahasa Jawa, } \\
\text { 'wong kabel telpon ja doyan kok' } \\
\text { ke dalam tuturan bahasa } \\
\text { Indonesia. }\end{array}$ \\
\hline 3 & $\begin{array}{l}\text { "the nikah experiment } \\
\text { tidak dikenal dalam } \\
\text { islam" }\end{array}$ & $\begin{array}{l}\text { Dalam ucapan tersebut } \\
\text { terdapat campur kode yang } \\
\text { berupa frase, yaitu masuknya } \\
\text { unsur bahasa Inggris, 'the nikah } \\
\text { experiment' ke dalam tuturan } \\
\text { bahasa Indonesia yang berarti } \\
\text { 'nikah percobaan'. }\end{array}$ \\
\hline 4 & $\begin{array}{l}\text { "maka nabi } \\
\text { memberikan stressing" }\end{array}$ & $\begin{array}{l}\text { Dalam ucapan tersebut } \\
\text { terdapat campur kode yang } \\
\text { berupa kata, yaitu masuknya } \\
\text { unsur bahasa Inggris, } \\
\text { 'stressing' ke dalam tuturan } \\
\text { bahasa Indonesia yang berarti } \\
\text { 'penekanan'. }\end{array}$ \\
\hline 5 & $\begin{array}{l}\text { "sekarang dia cantik of } \\
\text { course" }\end{array}$ & $\begin{array}{l}\text { Dalam ucapan tersebut } \\
\text { terdapat campur kode yang } \\
\text { berupa idiom, yaitu masuknya } \\
\text { unsur bahasa Inggris, 'of } \\
\text { course' ke dalam tuturan } \\
\text { bahasa Indonesia yang berarti } \\
\text { 'tentu'. }\end{array}$ \\
\hline 6 & $\begin{array}{l}\text { "sedang sweet } \\
\text { seventeenan" }\end{array}$ & $\begin{array}{l}\text { Dalam ucapan tersebut } \\
\text { terdapat campur kode yang } \\
\text { berupa frase, yaitu masuknya }\end{array}$ \\
\hline
\end{tabular}




\begin{tabular}{|c|l|l|}
\hline NO & \multicolumn{1}{|c|}{ TEKS } & \multicolumn{1}{c|}{ ANALISIS } \\
\hline 7 & $\begin{array}{l}\text { unsur bahasa Inggris, 'sweet } \\
\text { seventeenan' ke dalam tuturan } \\
\text { bahasa Indonesia yang berarti } \\
\text { '17 tahun yang indah'. }\end{array}$ \\
\hline $\begin{array}{l}\text { "akan timbul } \\
\text { understanding }\end{array}$ & $\begin{array}{l}\text { Dalam ucapan tersebut } \\
\text { terdapat campur kode yang } \\
\text { berupa kata, yaitu masuknya } \\
\text { unsur bahasa Inggris, } \\
\text { 'understanding' ke dalam } \\
\text { tuturan bahasa Indonesia } \\
\text { yang berarti 'pemahaman'. }\end{array}$ \\
\hline 8 & $\begin{array}{l}\text { kalo sudah ada saling } \\
\text { pengertian akan } \\
\text { timbul ketenagan } \\
\text { feeling of security". }\end{array}$ & $\begin{array}{l}\text { Dalam ucapan tersebut } \\
\text { terdapat campur kode yang } \\
\text { berupa frase, yaitu masuknya } \\
\text { unsur bahasa Inggris, 'feeling of } \\
\text { security' ke dalam tuturan } \\
\text { bahasa Indonesia yang berarti } \\
\text { 'rasa aman'. }\end{array}$ \\
\hline
\end{tabular}

3. Rekaman ceramah berjudul "Refomasi Baginda Nabi Muhammad SAW"

\begin{tabular}{|c|c|l|}
\hline NO & \multicolumn{1}{|c|}{ TEKS } & \multicolumn{1}{c|}{ ANALISIS } \\
\hline 1 & $\begin{array}{l}\text { "besok lewat sini jatuh } \\
\text { lagi, goblok tenan itu” }\end{array}$ & $\begin{array}{l}\text { Dalam ucapan tersebut } \\
\text { terdapat campur kode yang } \\
\text { berupa frase, yaitu masuknya } \\
\text { unsur bahasa Jawa, 'goblok } \\
\text { tenan' ke dalam tuturan } \\
\text { bahasa Indonesia yang berarti } \\
\text { 'bodoh sekali'. }\end{array}$ \\
\hline
\end{tabular}


Muhamad Fathoni : Analisis Campur Kode Dalam Ceramah Kyai Haji Zainuddin MZ (Kajian Sosiolungistik)

\begin{tabular}{|c|c|c|}
\hline NO & TEKS & ANALISIS \\
\hline 2 & $\begin{array}{l}\text { "kita datang dari } \\
\text { sebelah lor, sebelah } \\
\text { kidul, sebelah wetan, } \\
\text { sebelah kulon" }\end{array}$ & $\begin{array}{l}\text { Dalam ucapan tersebut } \\
\text { terdapat campur kode yang } \\
\text { berupa kata, yaitu masuknya } \\
\text { unsur bahasa Jawa, 'lor, kidul, } \\
\text { wetan, dan kulon' ke dalam } \\
\text { tuturan bahasa Indonesia } \\
\text { yang berarti 'utara, selatan, } \\
\text { timur dan barat'. }\end{array}$ \\
\hline 3 & $\begin{array}{l}\text { "Begini wong cilik } \\
\text { sudah jatuh terimpa } \\
\text { tangga" }\end{array}$ & $\begin{array}{l}\text { Dalam ucapan tersebut } \\
\text { terdapat campur kode yang } \\
\text { berupa frase, yaitu masuknya } \\
\text { unsur bahasa Jawa, 'wong cilik' } \\
\text { ke dalam tuturan bahasa } \\
\text { Indonesia yang berarti 'orang } \\
\text { kecil'. }\end{array}$ \\
\hline 4 & $\begin{array}{l}\text { "apa maksudnya aku } \\
\text { gak ngerti itu lah pak" }\end{array}$ & $\begin{array}{l}\text { Dalam ucapan tersebut } \\
\text { terdapat campur kode yang } \\
\text { berupa klausa, yaitu } \\
\text { masuknya unsur bahasa Jawa, } \\
\text { 'aku gak ngerti itu lah pak' ke } \\
\text { dalam tuturan bahasa } \\
\text { Indonesia yang berarti 'saya } \\
\text { tidak paham itu pak'. }\end{array}$ \\
\hline 5 & "wes gorene-gorene", & $\begin{array}{l}\text { Dalam ucapan tersebut } \\
\text { terdapat campur kode yang } \\
\text { berupa frase, yaitu masuknya } \\
\text { unsur bahasa Jawa, 'wes } \\
\text { gorene-gorene' ke dalam } \\
\text { tuturan bahasa Indonesia } \\
\text { yang berarti 'bawa kesini'. }\end{array}$ \\
\hline
\end{tabular}




\begin{tabular}{|c|l|l|}
\hline NO & \multicolumn{1}{|c|}{ TEKS } & \multicolumn{1}{c|}{ ANALISIS } \\
\hline 6 & "ini nek coro kita" & $\begin{array}{l}\text { Dalam ucapan tersebut } \\
\text { terdapat campur kode yang } \\
\text { berupa frase, yaitu masuknya } \\
\text { unsur bahasa Jawa, 'nek coro' } \\
\text { ke dalam tuturan bahasa } \\
\text { Indonesia yang berarti 'kalau } \\
\text { cara'. }\end{array}$ \\
\hline 7 & $\begin{array}{l}\text { "kalo saja tidak ada } \\
\text { akhirat sesudah dunia, } \\
\text { persilahkan hiduplah } \\
\text { sak enake dewe, nek perlu } \\
\text { sak penae wudelmu } \\
\text { dewe" }\end{array}$ & $\begin{array}{l}\text { Dalam ucapan tersebut } \\
\text { terdapat campur kode yang } \\
\text { berupa klausa, yaitu } \\
\text { masuknya unsur bahasa Jawa, } \\
\text { 'sak enake dewe, nek perlu sak } \\
\text { penae wudelmu dewe' ke dalam } \\
\text { tuturan bahasa Indonesia . }\end{array}$ \\
\hline
\end{tabular}

4. Rekaman ceramah berjudul "Akhirat"

\begin{tabular}{|c|c|c|}
\hline NO & TEKS & ANALISIS \\
\hline 1 & $\begin{array}{l}\text { "itu nanti bangkit } \\
\text { mukanya muka tikus, } \\
\text { na'udlubillahi min dalik" }\end{array}$ & $\begin{array}{l}\text { Dalam ucapan tersebut } \\
\text { terdapat campur kode yang } \\
\text { berupa klausa, yaitu } \\
\text { masuknya unsur bahasa Arab, } \\
\text { 'na'udlubillahi min dalik' ke } \\
\text { dalam tuturan bahasa } \\
\text { Indonesia yang berarti 'kita } \\
\text { berlindung kepada Allah dari } \\
\text { hal itu'. }\end{array}$ \\
\hline 2 & $\begin{array}{l}\text { "kita ini kan makhluk } \\
\text { zone politicum makhluk } \\
\text { yang tidak bisa hidup }\end{array}$ & $\begin{array}{l}\text { Dalam ucapan tersebut } \\
\text { terdapat campur kode yang } \\
\text { berupa frase, yaitu masuknya }\end{array}$ \\
\hline
\end{tabular}


Muhamad Fathoni : Analisis Campur Kode Dalam Ceramah Kyai Haji Zainuddin MZ (Kajian Sosiolungistik)

\begin{tabular}{|c|c|c|}
\hline NO & TEKS & ANALISIS \\
\hline & sendiri-sendiri" & $\begin{array}{l}\text { unsur bahasa Inggris 'zone } \\
\text { politicum' ke dalam tuturan } \\
\text { bahasa Indonesia. }\end{array}$ \\
\hline 3 & $\begin{array}{l}\text { "yang akan } \\
\text { memdapatang } \\
\text { perlindungan dari } \\
\text { Allah yang pertama } \\
\text { adalah Imamu 'Adil" }\end{array}$ & $\begin{array}{l}\text { Dalam ucapan tersebut } \\
\text { terdapat campur kode yang } \\
\text { berupa frase, yaitu masuknya } \\
\text { unsur bahasa Arab, 'Imamu } \\
\text { 'Adil' ke dalam tuturan } \\
\text { bahasa Indonesia yang } \\
\text { berarti 'imam yang adil'. }\end{array}$ \\
\hline 4 & $\begin{array}{l}\text { "siap yang diangkat } \\
\text { menjadi imam } \\
\text { pertama A'lamuhum } \\
\text { orang paling alim } \\
\text { dikampungmu siapa" }\end{array}$ & $\begin{array}{l}\text { Dalam ucapan tersebut } \\
\text { terdapat campur kode yang } \\
\text { berupa kata, yaitu masuknya } \\
\text { unsur bahasa Arab, } \\
\text { 'A'lamuhum' ke dalam tuturan } \\
\text { bahasa Indonesia yang } \\
\text { berarti 'yang palih alim'. }\end{array}$ \\
\hline 5 & $\begin{array}{l}\text { "Pak dikampung saya } \\
\text { ada dua orang yang } \\
\text { mana yang jadi imam? } \\
\text { Afshokhuhum yang } \\
\text { lebih fasih lidahnya" }\end{array}$ & $\begin{array}{l}\text { Dalam ucapan tersebut } \\
\text { terdapat campur kode yang } \\
\text { berupa kata, yaitu masuknya } \\
\text { unsur bahasa Arab, } \\
\text { 'Afshokhuhum' ke dalam } \\
\text { tuturan bahasa Indonesia } \\
\text { yang berarti 'ya paling fasih'. }\end{array}$ \\
\hline 6 & $\begin{array}{l}\text { "Yang paling pandai } \\
\text { menyuarakan aspirasi } \\
\text { rakyatnya, punya sains } \\
\text { of crises" }\end{array}$ & $\begin{array}{l}\text { Dalam ucapan tersebut } \\
\text { terdapat campur kode yang } \\
\text { berupa frase, yaitu masuknya } \\
\text { unsur bahasa Inggris 'sains of } \\
\text { crises' ke dalam tuturan } \\
\text { bahasa Indonesia. }\end{array}$ \\
\hline
\end{tabular}




\begin{tabular}{|c|c|c|}
\hline NO & TEKS & ANALISIS \\
\hline 7 & $\begin{array}{l}\text { "Pak ini Imam pelo, } \\
\text { makmum pelo, sah, } \\
\text { namanya kampung } \\
\text { pelo" }\end{array}$ & $\begin{array}{l}\text { Dalam ucapan tersebut } \\
\text { terdapat campur kode yang } \\
\text { berupa kata, yaitu masuknya } \\
\text { unsur bahasa gaul, 'pelo' ke } \\
\text { dalam tuturan bahasa } \\
\text { Indonesia yang berarti } \\
\text { 'bodoh'. }\end{array}$ \\
\hline 8 & $\begin{array}{l}\text { "Pak dua orang } \\
\text { alimnya sama, } \\
\text { fasihnya sama yang } \\
\text { mana yang jadi imam? } \\
\text { Aktsaruhum sinan,yang } \\
\text { lebih tua umrnya" }\end{array}$ & $\begin{array}{l}\text { Dalam ucapan tersebut } \\
\text { terdapat campur kode yang } \\
\text { berupa frase, yaitu masuknya } \\
\text { unsur bahasa Arab, } \\
\text { 'Aktsaruhum sinan' ke dalam } \\
\text { tuturan bahasa Indonesia } \\
\text { yang berarti 'lebih tua'. }\end{array}$ \\
\hline 9 & $\begin{array}{l}\text { "lahirnya bareng pak } \\
\text { awaluhum hjjjratan } \\
\text { yang pertama tinggal } \\
\text { disitu" }\end{array}$ & $\begin{array}{l}\text { Dalam ucapan tersebut } \\
\text { terdapat campur kode yang } \\
\text { berupa frase, yaitu masuknya } \\
\text { unsur bahasa Arab, 'awaluhum } \\
\text { hjjjratan' ke dalam tuturan } \\
\text { bahasa Indonesia yang } \\
\text { berarti 'yang lebih pertama } \\
\text { tinggal'. }\end{array}$ \\
\hline 10 & $\begin{array}{l}\text { "yang kedua syab } \\
\text { nasa'a } f l \text { 'Ibadatillah } \\
\text { anak muda yang tekun } \\
\text { beribadah kepada } \\
\text { Allah" }\end{array}$ & $\begin{array}{l}\text { Dalam ucapan tersebut } \\
\text { terdapat campur kode yang } \\
\text { berupa klausa, yaitu } \\
\text { masuknya unsur bahasa Arab, } \\
\text { 'syab nasa'a fl 'Ibadatillah' ke } \\
\text { dalam tuturan bahasa } \\
\text { Indonesia yang berarti } \\
\text { 'pemuda yang taat beribadah'. }\end{array}$ \\
\hline
\end{tabular}


Muhamad Fathoni : Analisis Campur Kode Dalam Ceramah Kyai Haji Zainuddin MZ (Kajian Sosiolungistik)

\begin{tabular}{|c|l|l|}
\hline NO & \multicolumn{1}{|c|}{ TEKS } & \multicolumn{1}{c|}{ ANALISIS } \\
\hline 11 & $\begin{array}{l}\text { "tapi yang 30 tahun } \\
\text { kebawah adik-adik } \\
\text { saya ini the next } \\
\text { generation" }\end{array}$ & $\begin{array}{l}\text { Dalam ucapan tersebut } \\
\text { terdapat campur kode yang } \\
\text { berupa frase, yaitu masuknya } \\
\text { unsur bahasa Inggris, 'the next } \\
\text { generation' ke dalam tuturan } \\
\text { bahasa Indonesia yang } \\
\text { berarti 'generasi selanjutnya'. }\end{array}$ \\
\hline 12 & $\begin{array}{l}\text { "kalian yang menjadi } \\
\text { pilot project" }\end{array}$ & $\begin{array}{l}\text { Dalam ucapan tersebut } \\
\text { terdapat campur kode yang } \\
\text { berupa frase, yaitu masuknya } \\
\text { unsur bahasa Inggris, 'pilot } \\
\text { project' ke dalam tuturan } \\
\text { bahasa Indonesia yang } \\
\text { berarti 'proyek percobaan'. }\end{array}$ \\
\hline 13 & $\begin{array}{l}\text { "maka mengalirlah } \\
\text { frily, free sex, somenlifen } \\
\text { kumpul bersama } \\
\text { diluar nikah alias } \\
\text { kumpul kebo" }\end{array}$ & $\begin{array}{l}\text { Dalam ucapan tersebut } \\
\text { terdapat campur kode yang } \\
\text { berupa idiom, yaitu masuknya } \\
\text { unsur bahasa Inggris, 'frily, free } \\
\text { sex, somenlifen' ke dalam } \\
\text { tuturan bahasa Indonesia } \\
\text { yang berarti 'kumpul kebo'. }\end{array}$ \\
\hline 14 & $\begin{array}{l}\text { "kalau hari tuan } \\
\text { terlunta-lunta matinya } \\
\text { menteleng" } \\
\text { itu siapa? rajulun }\end{array}$ & $\begin{array}{l}\text { Dalam ucapan tersebut } \\
\text { terdapat campur kode yang } \\
\text { berupa kata, yaitu masuknya } \\
\text { unsur bahasa Jawa, 'menteleng' } \\
\text { ke dalam tuturan bahasa } \\
\text { Indonesia. }\end{array}$ \\
\hline \multirow{2}{*}{$\begin{array}{l}\text { galam ucapan tersebut } \\
\text { terdapat campur kode yang } \\
\text { berupa klausa, yaitu }\end{array}$} \\
& & \\
& &
\end{tabular}




\begin{tabular}{|c|l|l|}
\hline NO & \multicolumn{1}{|c|}{ TEKS } & \multicolumn{1}{c|}{ ANALISIS } \\
\hline \multirow{1}{*}{16} & $\begin{array}{l}\text { qolbuhu mu'alakun bil } \\
\text { masajid.seseorang yang } \\
\text { hatinya sellau terpaut } \\
\text { pada masjid." }\end{array}$ & $\begin{array}{l}\text { masuknya unsur bahasa Arab, } \\
\text { 'rajulun qolbuhu mu'alakun bil } \\
\text { masajid' ke dalam tuturan } \\
\text { bahasa Indonesia yang berarti } \\
\text { 'seseorang yang hatinya sellau } \\
\text { terpaut pada masjid' }\end{array}$ \\
\hline & $\begin{array}{l}\text { "orang tua tengah } \\
\text { malam nyusu, bayi } \\
\text { tanpa dosa dibuang" }\end{array}$ & $\begin{array}{l}\text { Dalam ucapan tersebut } \\
\text { terdapat campur kode yang } \\
\text { berupa kata, yaitu masuknya } \\
\text { unsur bahasa Jawa, 'nyusu' ke } \\
\text { dalam tuturan bahasa } \\
\text { Indonesia. }\end{array}$ \\
\hline
\end{tabular}

Analisis campur kode yang terdapat dalam ceramah $\mathrm{KH}$. Zainuddin M.Z dengan berjudul: Jaman Susah, Keluarga Sakinah, Refomasi Baginda Nabi Muhammad SAW, dan Akhirat, yaitu sebagai berikut:

1. Bentuk-bentuk campur kode yang terdapat dalam ceramah $\mathrm{KH}$. Zainuddin M.Z. ada empat bentuk penyisipan yaitu:

a. Penyisipan unsur-unsur yang berwujud kata

b. Penyisipan unsur-unsur yang berwujud frase

c. Penyisipan unsur-unsur yang berwujud idom

d. Penyisipan unsur-unsur yang berwujud bentuk klausa.

2. Jenis campur kode dalam ceramah KH. Zainuddin M.Z., terdapat dua jenis campur kode, yaitu: 
Muhamad Fathoni : Analisis Campur Kode Dalam Ceramah Kyai Haji Zainuddin MZ (Kajian Sosiolungistik)

a. Campur kode keluar (outer code-mixing), karena bahasa yang dicampurkan merupakan bahasa asing yakni bahasa Arab dan bahasa Inggris

b. Campur kode ke dalam (Inner Code Mixing), karena bahasa yang dicampurkan merupakan bahasa daerah yakni bahasa Jawa.

3. Fungsi campur kode dalam ceramah KH. Zainuddin M.Z., yaitu:

a. Campur kode sebagai perulangan

b. Campur kode sebagai penyisip kalimat,

c. Campur kode sebagai kutipan.

4. Faktor penyebab terjadinya campur kode dalam ceramah $\mathrm{KH}$. Zainuddin M.Z yaitu:

a. Faktor penutur sendiri

b. Faktor kebiasaan.

\section{Kesimpulan}

Hasil analisis yang diperoleh dari penelitian ini adalah: (1) bentuk-bentuk campur kode yang terdapat dalam ceramah $\mathrm{KH}$. Zainuddin M.Z. ada empat bentuk penyisipan yaitu: penyisipan unsur-unsur yang berwujud kata, penyisipan unsur-unsur yang berwujud frase, penyisipan unsur-unsur yang berwujud idom dan penyisipan unsur-unsur yang berwujud bentuk klausa. (2) Jenis campur kode dalam ceramah KH. Zainuddin M.Z. merupakan campur kode keluar (outer code-mixing), karena bahasa yang dicampurkan merupakan bahasa asing yakni bahasa Arab dan 
Muhamad Fathoni : Analisis Campur Kode Dalam Ceramah Kyai Haji Zainuddin MZ

(Kajian Sosiolungistik)

bahasa Inggris, dan campur kode ke dalam (Inner Code Mixing), karena bahasa yang dicampurkan merupakan bahasa daerah yakni bahasa Jawa. (3) Fungsi campur kode dalam ceramah $\mathrm{KH}$. Zainuddin M.Z yaitu: sebagai perulangan, sebagai penyisip kalimat, dan sebagai kutipan. Adapun (4) faktor penyebab terjadinya campur kode dalam ceramah KH. Zainuddin M.Z yaitu: faktor penutur sendiri dan faktor kebiasaan. 
Muhamad Fathoni : Analisis Campur Kode Dalam Ceramah Kyai Haji Zainuddin MZ (Kajian Sosiolungistik)

\section{Daftar Pustaka}

Abdul Chaer dan Leonie Agustina, Sosiolinguistik: Perkenalan Awal, Jakarta: Rineka Cipta, 2014

Harimurti Kridalaksana, Kamus Linguistik, Jakarta: Gramedia Pustaka Utama, 2008

Kunjana Rahardi, Kajian Sosiolinguistik. Bogor: Ghalia Indonesia, 2010

Nababan, P.W.J., Sosioliguistik Suatu Pengajaran, Jakarta: Gramedia, 1983 